\title{
"NICARAGUAN WORDS": \\ JOSÉ CORONEL, THE VANGUARDIA, \\ AND WHITMAN'S "LANGUAGE \\ EXPERIMENT"
}

\section{KELLY SCOTT FRANKLIN}

IN A 1953 memoir, José Coronel Urtecho, the founder of the Nicaraguan avant-garde, recalls the shock of a US visitor who noticed a portrait of Walt Whitman in Coronel's isolated estate along the San Juan River, near the border of Costa Rica. Coronel wrote that for his Yankee guest to find Whitman in rural Nicaragua "surprised him as much as finding a caiman on Beacon Street or a tapir grazing tranquilly in Boston Common." Coronel's surreal language frames a strange, exotic-animal Walt who can somehow nonetheless (notice that he is "grazing tranquilly") be calmly and easily translated into any new context (Rápido 27). Indeed, the relations between the US and Latin America, of which this portrait-encounter represents an intriguing instance, have often been shaped by both this mutual exotic fascination and by countless literary and cultural translations, intersections, and crosscurrents. ${ }^{2}$

What was Whitman doing in Nicaragua? In fact, US and Nicaraguan histories have been inextricably linked since the mid-nineteenth century, when traffic from the California Gold Rush (18481855) across Nicaragua's short inter-oceanic route brought a sudden influx of US capital and culture. ${ }^{3}$ Later in the 1850s, Tennessee filibuster William Walker took advantage of civil war in Nicaragua to seize power and become-in one of the stranger moments in US history-president of Nicaragua until he was expelled by a Central American coalition. By the early twentieth century, a painful contradiction lay at the heart of Nicaraguan culture: Michele Gobat persuasively argues that while Nicaragua sought to imitate the prosperity and power of the US, many Nicaraguans fiercely resented the United States' frequent military, cultural, and financial interventions into their 
national affairs. ${ }^{4}$ And in fact, José Coronel himself evinced a conflicted attitude, writing: "My personal attitude towards the United States was for many years ambivalent: I found myself attracted, I would almost say fascinated, and at the same time repelled by them."

But if US involvement in Nicaragua repelled Coronel, US literature had attracted him from a very early age. Having as a child first encountered Whitman in Spanish translation and then in Whitman's native tongue, Coronel once claimed, "I can almost say that I learned to read English reading Poe and Whitman" (Rápido 51). ${ }^{6}$ From 1924 to 1927, while many of his peers went to Europe, the young Coronel chose to live and study in San Francisco, California, where he immersed himself in US literature. When he returned, however, he founded an avant-garde movement that vocally denounced the continued US intervention in Nicaragua, and called for the creation of an authentic, autochthonous Nicaraguan literature and culture. Yet despite this agenda, Coronel's Vanguardia, as it came to be called, remained strongly (and paradoxically) permeated by US literary culture, for Coronel had begun what would be a lifetime of serious engagement with US writers, with Walt Whitman occupying a prominent place.

Indeed, among Latin American avant-garde writers, José Coronel stands out for his depth of reading in Whitman's work. As a poet and a translator, Coronel knew Leaves of Grass, and anthologized poems from it in three different collections. ${ }^{7}$ Yet few scholars have studied this long trans-continental literary relationship. ${ }^{8}$ So what did Coronel find compelling in Whitman's work? At stake here is not only an accurate vision of hemispheric literary history, but also an understanding of the real overlap between aesthetics and politics in twentieth-century US-Nicaraguan relations, because the texts of Coronel's group, and the politics of its members, would seriously impact the course of Nicaraguan literature and history. A reading of Coronel's later writings on Whitman, alongside the texts of his Vanguardia, reveals Whitman's presence, as the Nicaraguan avant-garde forged a nationalist, autochthonous literature that sought at the same time to be aesthetically new. This essay argues that Coronel gravitates to Whitman because of the US poet's project of formulating in his verse a truly independent "American" culture, particularly through what Whitman called his 
"language experiment"; Coronel's consistent emphasis on this aspect of Whitman's project reveals that he thinks of it as a precursor to the very similar war of linguistic and cultural independence that he and his Vanguardia waged against the influence and intervention of the US in Nicaragua.

While most of Coronel's writings on Whitman come from his post-Vanguardia days, an early piece from 1927-published in the very year he returned to Nicaragua from the US - reveals that he was already reading Whitman as having helped initiate the United States' literary and cultural independence from the Old World. In an article in the newspaper El diario nicaragüense titled "Los yanquis, poetas" ["The Yankees, Poets"], Coronel wrote: "In outdated books that are spiritual manuals among us[,] the old assertion is still made that the Yankees are literary colonists of England." Coronel briefly refutes this charge by arguing that Poe and Whitman have in fact launched US literature in its own right onto the world stage, and goes on to offer a longer survey of US poetry of the twentieth century, citing the contributions of writers like Eliot, Pound, Sandburg, and Frost. ${ }^{10}$

Throughout his career, Coronel would repeatedly describe Whitman (and Poe) in terms of this notion of literary and cultural independence. In his 1946-47 "Anotaciones sobre literatura norteamericana" ["Annotations on US Literature"], he says this of Whitmanto whom he devotes over half of the article's ten pages: ${ }^{11}$

To take ... everything, from new perspectives, new points of view distinct from the old ones, with a new liberty and independence to create a new poetry that could form, in its turn, a new type of man ... this was Whitman's ideal. And for him it should also be the ideal of American literature. ${ }^{12}$

In his 1949 Panorama y antología de la poesía norteamericana [Panorama and Anthology of US Poetry], Coronel also describes Whitman as a "genius of the true American Independence, of the permanent revolutionary spirit of the lands and people of America."13 Likewise, in a later conference, he praised Rubén Darió, Poe, and Whitman as "the trinity granting independence, and even to a certain extent initiating, poetry proper to the American continent, and even perhaps in a certain sense [initiating] the culture of the American continent." ${ }^{\prime 4}$ As such, Coro- 
nel consistently reads Whitman as resisting literatures, traditions, and cultures that sought to impose their forms and themes on "American" letters-not a surprising reading, as we shall see, given Coronel's own struggle for Nicaraguan cultural and political independence.

Coronel sees Whitman as accomplishing this project of independence in his writings by a conscious expression and celebration of the unique national and cultural realities of the US and its territories. Readers of Whitman can see that, for the most part, rather than turning to Europe or the classical world for poetic materials, Whitman sought to capture the "American" experience in verse. In fact, this is what fascinated Coronel about Whitman from the beginning. Having first read Whitman in a translation by the Mexican poet and ambassador Amado Nervo, Coronel was from a young age attracted to Whitman's ambitious project of expressing a national culture in his poems: ${ }^{15}$ Whitman, he writes, was "the most 'American,' inconceivable outside of his country."16 "His poetry was for me from the beginning," Coronel continues, "and, in a certain way, even continues to be, the United States. ${ }^{117}$ In Whitman he found the Americas expressed in all their unique places and peoples: "a breadth of continental proportions, with immense open spaces and unlimited horizons, a powerful ocean breeze ... a unanimous chorus of millions of voices, a prophetic and multitudinous vision of uncountable peoples on the move," which was for him "the discovery, or I should say, the revelation of the world of the Americas." In In 1924, when he subsequently read Armando Vasseur's 1912 translation of Whitman, he glimpsed, but innocently downplayed, the expansionism some see in the US poet's verse: "I imagined," he writes, "motley multitudes invading peacefully territories without limits, crossing immense rivers. . . building everywhere thousands of towns and great cities, vibrating with machinery and vehicles." ${ }^{\prime 19}$

In his memoirs of the US, Rápido Tránsito [Rapid Transit], Coronel meditates on Whitman's ability to capture a nation and a culture in verse. He writes, "His poetry was of the land, and above all from the land and the people of America" (Rápido 51). ${ }^{20}$ Translating from and paraphrasing Whitman's "To Foreign Lands," Coronel continues: "I have heard it asked—he [Whitman] used to say—for something to 
decipher this enigma of America, and for that he was sending us his verses, so that we could contemplate in them what we desired" (Rápido 51). ${ }^{21}$ The Whitman whom Coronel celebrates is the poet of nation and hemisphere: "The beautiful bard of the white beard brought us a program of songs for America" (Rápido 52). ${ }^{22}$

Coronel proceeds in the memoir to highlight and translate sections from Whitman's poem "Starting from Paumanok," that create a cata$\log$ of all the realities particular to the US and its territories. He translates lines from Section 3 (Rápido 52):

For you a programme of chants.

Chants of the prairies,

Chants of the long-running Mississippi, and down to the Mexican sea,

Chants of Ohio, Indiana, Illinois, Iowa, Wisconsin and Minnesota, Chants going forth from the centre from Kansas and thence equidistant, Shooting in pulses of fire ceaseless to vivify all. ${ }^{23}$

On the next page Coronel translates a large portion of Section $14,{ }^{24}$ in which Whitman's speaker catalogues the specific natural resources of North America: "Land of coal and iron! land of gold! land of cotton, sugar, rice! / Land of wheat, beef, pork!" (Rápido 53). The translated section of Whitman's "American" catalog also includes indigenous construction techniques, such as "the healthy house of adobie!," as well as Whitman's naming of US rivers and lakes: "land of the Delaware! / Land of Ontario, Erie, Huron, Michigan!" It is a catalog of place, dramatically and exhaustively captured in verse.

By signaling these passages from Whitman's book, we can see Coronel pinpointing Whitman's attempt to express in poetry a specific national, geographic, and cultural identity. But to Coronel, one of the most important accomplishments of Whitman's poetics of independence was in fact linguistic: his employment of vernacular, native, indigenous, and local diction, including slang, common language, and "nombres aborígenes" (Rápido 53). Coronel cites the extensive list of native words from Section 16 of "Starting from Paumanok": 25 "Okonee, Koosa, Ottawa, Monongahela, Sauk, Natchez, Chattahoochee, Kaqueta, Oronoco, / Wabash, Miami, Saginaw, Chippewa, Oshkosh, 
Walla-Walla" (Rápido 54). He is likewise drawn to indigenous words incorporated more directly into Whitman's American English, words like "moose," "chickadee," and "squaw" (Rápido 56).

Further shaping his interpretation of Whitman is the fact that José Coronel may very well be the only Latin American avant-gardist to have read from Whitman's posthumously-published collection of linguistic musings, An American Primer. Coronel quotes twice from it in his memoir: "Monongahela: it rolls with venison richness upon the palate" (Rápido 54). 26 "Era el poeta adámico," Coronel continues, quoting again from the Primer:

edénico, como Adán en el Paraíso dando nombre a las cosas. Estaba enamorado de todas las palabras y de todas las cosas, y quería para su lengua, como decía en su American Primer, palabras de Canadá, palabras yanquis, palabras de Manhattan, palabras de Virginia, palabras de Florida y de Alabama, palabras de Texas, palabras mexicanas y nicaragüenses, Mexican and Nicaraguan words. (Rápido 54) $^{27}$

For emphasis here, Coronel uses Whitman's own English wording from the American Primer to highlight the notion of an "American" language that springs organically from the New World soil to express its unique realities. Whitman becomes, then, a prime example of a poet who helped forge, through language and poetry, an independent American and cultural identity. It was a crucial notion for Coronel, and a look at the work of the avant-garde movement he founded reveals a very similar war of independence: a linguistic and artistic rebellion against the imperialist presence and influence of the US in Nicaragua.

Upon his return from California in 1927, Coronel launched this rebellion, the same year as the Nicaraguan resistance fighter Augusto Sandino and his band of guerillas began their bloody, six-year war for Nicaraguan autonomy. While rifles echoed in the jungles of Nicaragua, Coronel gathered a small group of writers and artists, and began to cast about for ways to fashion a new literature that could reinvigorate Nicaraguan cultural identity in the shadow of US intervention. The project began to take shape as the group published in newspapers and reviews. Coronel himself co-directed La Semana, a conservative, weekly Managua review that called for "autochthonous literature, 
tasting of Nicaragua," and promoted the arts as "forces generative of national culture. ${ }^{28}$ Nicaragua's young people, Coronel felt, lacked a sense of national identity: in an article from La Semana of June 17, 1928, he complained, "They are born foreigners to their native land and they attend a liberal school to emerge completely uprooted."29 For Coronel, the obstacle to a truly authentic Nicaraguan culture was the pervasive cultural influence of the US: in an article for the shortlived bimonthly Criterio, "¿Cuándo Comenzaremos?" ["When Will We Begin?"], on April 15, 1929, Coronel asks why Nicaraguan young people reject their own culture and prefer "a culture in formation, a cosmopolitan culture that is yankee culture." " "[W]hen will we, the Nicaraguan youth," Coronel asks, "begin to immerse ourselves in Nicaraguan culture?"31

In 1931 the Vanguardia published its first manifesto, calling for a promotion in Nicaragua of international avant-garde aesthetics, but at the same time promising to "give free rein to the emotion of being and being in Nicaragua," and "to begin the artistic re-creation of Nicaragua." ${ }^{32}$ By this point the group included, among others, the Paris-educated Luis Alberto Cabrales, the wunderkind Joaquín Pasos, the Columbia University-educated novelist and poet José Roman, and Pablo Antonio Cuadra, who publicly recited an early poem wearing boxing gloves and punctuating each stanza with punches in the air (Arellano 32). The group's manifesto promised a literary revolution in which they would use "even the literary dynamite and rifle," and they made good on their promise in the same year, when, following a precedent set by many of the global avant-gardes, the group had its first public recital, a theatrical event that included costumes, sound effects, and readings of poetry. ${ }^{33}$ As the movement's early chronicler, Jorge Eduardo Arellano describes the event as a scandal, and therefore a success: "The recital's success was complete. In Granada it exploded like a bomb. It was claimed that there had been recitations of immoral poems, a complaint that reached the ears of the Bishop. But the Salesians [a Catholic religious order] defended the vanguardistas and the matter was closed" (Arellano 33). ${ }^{34}$ As it had been for Whitman's Leaves of Grass after its 1882 "banning" in Boston, even scandalous publicity was still good publicity for the Vanguardia; and 
it is no coincidence that their leader would look to such a self-consciously polarizing and provocative figure as Whitman as a precursor to his project of renovating Nicaraguan culture.

In its creative writings, the movement began aggressively to respond by attacking the dissipating influence of US culture on Nicaraguan identity, and poetically celebrating and preserving distinctly Nicaraguan realities. "La Fratria Nicaragüense" ["The Nicaraguan Brotherhood"], an early anonymous manifesto-article published in the group's periodical Vanguardia in 1932, decries the loss of Nicaraguan identity:

Our language is being lost.

Our religion is being lost.

Our honor is being lost.

Our land is being lost.

Intervention is attempting the conquest of our people. ${ }^{35}$

Speaking for the Vanguardia, the manifesto reveals what the movement, and some Nicaraguans, felt was at stake: the dissipation and loss of Nicaraguan culture in the face of foreign influence.

In fact, as this manifesto suggests, language would be one of the major sites of conflict between the Nicaraguan Vanguardia and external cultural intervention, as we can see in José Román's poem "Preludio a Managua en B Flat" ["Prelude to Managua in B Flat"]. Román begins by fondly describing the city of Managua with a Whitmanesque urban catalogue:

Paved streets, carts and buses. Lagoons that dream like old poets and a laughing lake, that sings that trembles elegant Folk cars, wagons, Indians, beggars. . . ${ }^{36}$

But the city life is overshadowed the heavy US presence in the Nicaraguan capital:

El Canal, los yanquis y los liberales, los conservadores

y toda política, locas ilusiones ... .

Leche pasteurizada y Club y Jazz Band

y por todas partes un English Spoken. 
"Cuantos millones de almas hablaremos inglés." Yes Sir. ${ }^{37}$

Here the invasion proceeds simultaneously on cultural and linguistic fronts, as Nicaraguan realities get steadily crowded out by those of the US.

Román continues to decry the effects of this intervention on Nicaraguan language, complaining that "everything is foreign," and that "even your cathedral is imported. . . . Soon we'll see in it an English Speaking God. "'38 And even "el Gran Momotombo," the great volcano on the shores of Lake Managua, must speak English: "cuando se despierte le dirás: No Spanish." 39 The last five lines are almost entirely English as the US (and other foreign) influence reaches its peak at the end of the poem:

Zoos

Golf y Country Clubs, Canal Zone, German, French, English Spoken ...

Managua.

Yes Sir.

Not only has English eclipsed Spanish in the poem, but the final two words "Yes Sir" also represent a statement of obedience, an act of subservience to a dominating foreign presence. To fight this oppressive outside influence on Nicaraguan language and culture, the Vanguardia, like Whitman, would set themselves to capture and express what they believed to be their culture's true and authentic indigenous language.

In her book Latin American Vanguards: The Art of Contentious Encounters, Vicky Unruh has shown that "in Latin America vanguardist inquiries into language were often marked by concrete cultural problems," and that the avant-gardes were attuned to "language as the site of cultural and social tensions." ${ }^{40}$ Vera Kutzinski takes this a step further to argue that a valorization of indigenous, regional, or other particular ethnic languages and aesthetics frequently formed part of a nationalist rhetorical strategy resisting imperialism. ${ }^{41}$ Of course, a rhetorical strategy which claims to return to an original or originary language or culture in order to self-differentiate from or resist an 
outside invader is not without its risks - more especially coming from a group of privileged, predominantly white granadinos like the members of the Vanguardia. ${ }^{42}$ Although charges of inauthenticity leveled against non-indigenous persons who use or participate in indigenous or indigenist cultural production can sometimes simply enact a different version of an old power struggle, nevertheless it would be fair to question to what extent the Vanguardia was truly invested in indigeneity as a reality integral to Nicaraguan experience.

What we see, then, in Coronel's fascination with Whitman's language experiment, is that both Whitman's work and Coronel's Vanguardia participate in a transnational project of vernacular and indigenous language recuperation, but one that runs parallel to, without intersecting, what Chadwick Allen calls the "trans-Indigenous." That is to say that rather than what Allen sees as the potential for a global indigeneity, Whitman and Coronel share a model that co-opts the indigeneity of their nation's past and present to serve non-indigenous ends: ${ }^{44}$ rather than expressing the experiences or serving the interests of indigenous peoples and their literatures or cultures, this linguistic act instead serves to bolster the aims of a fierce nationalism. ${ }^{45}$ Nonetheless, even with its faults, we can understand the Vanguardia's move as a strategy of linguistic resistance to US intervention, a strategy of which Coronel clearly regards Whitman as a precursor.

To address this problem, the Vanguardia sought, as they put it in their manifesto, to "return to the center" ["volver al centro"] of Nicaraguan culture, and to do this, these writers employed the weapon of Nicaraguan words. ${ }^{46}$ Pablo Antonio Cuadra's 1934 Poemas Nicaragüenses [Nicaraguan Poems] represents perhaps the clearest poetic example of this, employing a rhetorical strategy of indigenous speech and vocabulary to resist the cultural crisis precipitated by US imperialism. ${ }^{47}$ Cuadra celebrates the Nicaraguan landscape, its regions, its flora and fauna, its myths and its natives, while employing a language that is not simply Spanish, but specifically Nicaraguan. In his "Inventario de Algunos Recuerdos" ["Inventory of Some Memories"], Cuadra refers to drinking a "jícara" of "tiste," two words of náhuatl origins referring to a gourd-cup and a chocolate beverage; ${ }^{48}$ he likewise describes the sky as an "upside-down basket" ["el guacal invertido"], using another 
word of náhuatl origin, guacal, meaning basket. ${ }^{49} \mathrm{He}$ also populates his "Oda de Amor" ["Ode of Love"] with New World fauna, many with indigenous names: "zenzontle" [mockingbird], "colibrí" [hummingbird], and "chocoyo" [parrot]..$^{50}$

For the Vanguardia, then, these Nicaraguan words became a way to write back against the cultural and military imperialism of the United States. In Poemas Nicaragüenses, Cuadra even dramatizes a Nicaraguan verbal and linguistic resistance in military form, with his "Poema del Momento Extranjero en el Bosque" ["Poem of the Foreign Moment in the Jungle"], which describes a failed US military expedition into the jungle of Nicaragua. In the poem, the US soldiers kill Nicaraguan men, seduce their women, trample the crops, and violate the natural landscape with their technology by putting up "an iron tree at a parallel height to the coconut palm." ${ }^{\text {51 }}$ But the heart of Nicaragua rebels against this foreign incursion, and "the whole of our civilized savagisms / refuge of the ignored justice of the sonorous and green temple / Pours out a protest, proudly tiny. ${ }^{\prime 52}$ In the poem, Nicaraguan nature routs the invaders: "And behold, we are witness to the hasty retreat of 500 Americans / Pallidly defeated by our angry and avenging malaria." ${ }^{53}$ Here it is not superior firepower, military tactics, or diplomacy that defeats foreign intervention, but rather mosquitos carrying disease; and Cuadra's word choice describes these Nicaraguan insects as a "protest," suggesting that the mosquitoes could be read as a stand-in for Nicaraguan words themselves. Indeed, Poemas Nicaragüenses even concludes with a glossary in which Cuadra defines and explains the indigenous Nicaraguan vocabulary, as well as the regions, geographical features, flora, and fauna particular to Nicaragua, turning a book of poetry into a pedagogical tool that in itself enacts a dramatic cultural resistance to the foreign influence and intervention of the United States.

This aesthetic and cultural project of Nicaraguan autochthonism partially explains the Vanguardia's somewhat paradoxical support of the guerrilla leader, Augusto Sandino. ${ }^{54}$ Although Sandino's leftism troubled them and their fellow conservatives, they had welcomed his plan for strengthening Nicaragua against US intervention through an authoritarian nationalism that rejected the bourgeoisie and valorized 
a notion of mestizaje or racial mixture. ${ }^{55}$ However much we may see the Vanguardia's engagement of Nicaraguan indigenous language and culture as merely an idea or an elite nationalist construct, Sandino's notion of mestizaje as a cultural and national strengthener nonetheless parallels their plan for turning to Nicaraguan folk and indigenous culture for artistic and political renewal. However, when Sandino affirmed communist ideals in a highly-publicized self-proclamation, Nicaraguan conservatives severed their ties with him completely. ${ }^{56}$ Then, when Sandino was seized and executed on February 1, 1934, the Vanguardia's quest for a strong leader to bring about their vision for Nicaraguan politics and culture led them to the very man who had arranged Sandino's murder: Anastasio Somoza García, head of the US-created Nicaraguan National Guard. ${ }^{57}$

To understand this decision, we must understand that US interventions in Nicaragua in the late 1920s had radicalized many of the Conservative "oligarch" families of which the Vanguardistas were a part, and some had begun calling for an authoritarian style of government as the solution to Nicaragua's problems. Because of this, an aggressive right-wing political involvement went hand-in-hand with the Vanguardia's aesthetic production, and the movement clamored for a new form of government along the lines of Catholic corporatist dictatorships in Spain, Portugal, and Austria.$^{58}$ Influenced by the proto-fascist nationalism of Charles Maurras, Coronel and Luis Alberto Cabrales publicly denounced democracy (Arellano 55). In an article from 1929 titled "Invitación a Reaccionar" ["An Invitation to React"] Coronel condemned democracy as a form of government "false in itself and as such impracticable," and claimed that it "has been an instrument of deceit that mercenaries and the ambitious from everywhere have used to lead our people to the slaughter." 59 "Democracy," the young Coronel continued, "is a principle of disorder and chaos, deadly to the Latin peoples, and above all to us." ${ }^{90}$

When Somoza did take power in a 1936 coup, Coronel and some of the group were even rewarded for their loyalty with government positions. ${ }^{61}$ But Coronel and the Vanguardia would get more than they bargained for with their new leader, as Somoza launched a regime of fraud, corruption, and exploitation, rigging elections, using the govern- 
ment to enrich himself and his friends, and increasing Nicaragua's economic dependence on the US. ${ }^{62}$ Disgusted, many of the group eventually distanced themselves from the Somoza regime. ${ }^{63}$ In an interview in the early 1980s, Coronel could look back with dismay on the young Vanguardia's grievously misguided politics: "In the end, it was the madness of young men[;] we did not set ourselves to think seriously about the affair." ${ }^{\prime 4}$ Gradually disillusioned with the corruption of Somoza's regime, Coronel continues, "I did not want to do anything but to leave and to withdraw little by little, which is what I began to do. ${ }^{95}$ In 1977, Coronel had in fact begun to support the Sandinistas and in 1986 he would publish what Arellano calls "a hyperbolic tribute" ["un hiperbólico elogio"] to Carlos Fonseca, the founder of the Sandinistas. ${ }^{66}$

What is remarkable, then, is just how transformed-and perhaps even only half-recognizable - Whitman's project of cultural independence really becomes after Coronel absorbs it into the complicated and turbulent setting of twentieth-century Nicaraguan literature and politics. During their Vanguardia years, Coronel and his group had sought a literature and art that could forge an independent national identity by giving voice to the common experience of Nicaraguan reality, rooted in indigenous and vernacular folk culture; yet they rejected democracy, which would have given political agency to more of the actual speakers of that same autochthonous voice. ${ }^{67}$ What this means is that Coronel sought in one sense to divide the aesthetic from the political ramifications of Whitman's democratizing project, splitting into removable parts something that Whitman himself always imagined as inseparable. ${ }^{68}$ We might, however, see Coronel's embrace of the Sandinistas and the Nicaraguan Revolution as an attempt to reconcile this paradox by avoiding democracy yet endorsing a political system that springs up from the soil and people of Nicaragua. "I am not an enemy of strong governments as such," Coronel asserts in his 1980s interview, and, after admitting that Sandinismo is "a strong government," Coronel nonetheless defends it in terms that frame it as an autochthonous outgrowth of the people of Nicaragua: ${ }^{69}$

How could it not be a strong government if it is the government of the people? It 
identifies with the people. The Sandinistas are the conscious, fighting part, the part that has come emerging from the people itself and has never separated itself from that people, nor does it intend to separate, because it is totally identified, morally and intellectually with that people."

Whether or not Coronel's Sandinista enthusiasm overlies a felt need for atonement for the disastrous politics of his young avant-garde, he represents the Frente, as it was called, as the political manifestation of the cultural autochthony his Vanguardia once sought. ${ }^{71}$

In terms of political gain the Vanguardia's project of resistance and autonomy was, in its time, a failure. Yet the group's brief, explosive period of avant-garde creativity during that turbulent decade had marked Nicaraguan letters forever, as attested to by perhaps the most famous of contemporary Nicaraguan authors, the poet, priest, and one-time Sandinista Ernesto Cardenal. In 1948, Cardenal finished his thesis on the new poetry of Nicaragua at the National Autonomous University of Mexico, and in a chapter on the Vanguardia, Cardenal described what he called the movement's "national fight": 72 "The fight was long; but now, fifteen years later, those pages of the Vanguardia, now yellowed and faded, have triumphed completely among the youth." ${ }^{.73}$

Aesthetically, then, José Coronel and the Vanguardia had successfully pushed back against the US encroachments on Nicaraguan cultural autonomy, and we have seen from Coronel's writings on Whitman that he frames Whitman as an architect of a very real literary and cultural independence. For him, Whitman's project of celebrating and cementing "American" realities and language in writing represented a precursor for a new literature whose "Nicaraguan words" could fight back against US imperialism. Apart from illuminating an important and neglected literary cross-current in hemispheric American studies, as well as dramatizing the enduring relevance of language as a site of conflict over national and cultural identity, what does Whitman's poetic afterlife in Nicaragua suggest to scholars of Whitman and US literature? First, I argue that it should direct us back to look with fresh perspective at the extremity and power of Whitman's own act of linguistic resistance in An American Primer-from which Coronel quotes - against the literary and cultural dominance that Europe still exercised upon the nineteenth-century US. Second, the facili- 
ty with which Whitman can be appropriated into such a drastically different aesthetic and political context should provide opportunity for Whitman scholars and Americanists to reexamine preconceived notions we might have about both the universal value and the historical consequences of Whitman's projects.

It should be acknowledged that there is an inevitable tension within Whitman's writings on, and ideas about, the English language. On the one hand, Whitman frequently celebrated it as the "organic" evolutionary product of past languages and cultures, growing, expanding, absorbing, and preserving only what was generative and fruitful; ${ }^{74}$ but on the other hand lies Whitman's fierce nationalist desire for independence from his nation's erstwhile European colonial rulers, who still exerted an undeniable influence on US culture. I argue that this latter aspect of Whitman's writings deserves somewhat greater emphasis than it has received, and Coronel's reading of Whitman, after his own avant-garde linguistic struggle, directs us to re-examine the US poet's attempted "American" language revolution. ${ }^{75}$

It has in some ways become a commonplace to say that US literature in the nineteenth century was competing for autonomy against the influence of Europe. Still, it is easy to forget that although United States literature today has a certain level of global prestige, during the Colonial period and the first half of the nineteenth century, US literature was not always well regarded, even by US citizens. ${ }^{76}$ For although the colonies and subsequently the States had long been producing their own literature, in the nineteenth century Tennyson, Dickens, and the other European writers still held no little sway over the readership of our young nation. ${ }^{77}$ In 1820 , the acerbic English clergyman Sydney Smith had famously asked in The Edinburg Review: "In the four quarters of the globe, who reads an American book? Or goes to see an American play?." ${ }^{78}$ In 1835, the Frenchman Alexis de Tocqueville observed: "America has hitherto produced very few writers of distinction; it possesses no great historians, and not a single eminent poet." "79 Even Emerson himself admitted in his 1844 essay "The Poet," "I look in vain for the poet I describe" and "We have yet had no genius in America." ${ }^{\$ 0}$ To be fair, it was painting in pretty broad strokes for these men to claim that the nation whose authors already included J. 
Hector St. John de Crèvecoeur, Benjamin Franklin, Thomas Jefferson, Phyllis Wheatley, Washington Irving, and Margaret Fuller had as of yet no literary talent; but the truth is that Europe did, in fact, still exercise a great deal of cultural and literary dominance in the US. ${ }^{81}$ Enter Walt Whitman, in the 1850s, eager and ready to anoint himself the American bard and to strike for literary independence from the Europe.

One of the factors that might mask the extreme and pugilistic nature of his project is Whitman's own tendency throughout his career to use the language of growth and evolution rather than that of rupture; in his books, Whitman often denies any desire to reject the traditions, literatures, or cultures of the United States' European past. In his "Song of the Exposition," for instance, his speaker says, "We do not blame thee elder World, nor really separate ourselves from thee, / (Would the son separate himself from the father?)." ${ }^{82}$ In his Preface to the 1855 Leaves of Grass, the first words are "AMERICA does not repel the past or what it has produced under its forms or amid other politics or the idea of castes or the old religions." ${ }^{\prime 83}$ But his pose of magnanimity slips as he goes on to describe the inherited past as a "slough" which "still sticks to opinions and manners and literature" and as a "corpse ... slowly borne from the eating and sleeping rooms of the house." Likewise, in "Pioneers! O Pioneers!," Whitman's speaker says:

Have the elder races halted?

Do they droop and end their lesson, wearied over there beyond the seas?

We take up the task eternal, and the burden and the lesson,

Pioneers! O pioneers!

All the past we leave behind ${ }^{85}$

R.W.B. Lewis has rightly identified, if perhaps too-unquestioningly accepted, the pose of pastlessness and "artistic innocence" in Whitman's Adamic myth. ${ }^{86}$ However, Floyd Stovall has exhaustively documented the evidence we have of the countless authors and texts that shaped and influenced Whitman; ${ }^{87}$ Kenneth $M$. Price has likewise persuasively argued that we should regard Whitman's posturing of pure originality with some suspicion. ${ }^{88}$ It seems, then, that Whitman, if eclectically, immersed himself in both historical and international 
literature and thought, even while carefully shaping his own art to appear to have sprung up freshly from the New World. Still, Whitman's striking writings on the American language in his American Primer reveal just to what lengths he was willing to go to "leave the past behind" in his cultural war for independence against the so-called "Old World."

Late in life, Whitman once told his disciple Horace Traubel:

This subject of language interests me-interests me: I never quite get it out of my mind. I sometimes think the Leaves is only a language experiment. . . The new world, the new times, the new peoples, the new vista, need a tongue according - yes, what is more, will have such a tongue - will not be satisfied until it is evolved. ${ }^{89}$

We can see Whitman's early thoughts on this "language experiment" in a series of manuscript notes, written mainly in the $1850 \mathrm{~s}$, for a proposed series of lectures that he never delivered. When Traubel published the notes after Whitman's death, he titled it An American Primer, but the original manuscript bears the characteristically Whitmanian title: The Primer of Words: for American Young, Men, and Women, For Literats, Orators, Teachers, Musicians, Fudges, Presidents, Eंc. As Folsom and Warren have rightly pointed out, in his Primer notes, Whitman calls for a radical widening of the boundaries of so-called "proper" American language. "The appetite of the people of These States," Whitman writes, "in popular speeches and writings, is for unhemmed latitude, coarseness, directness, live epithets, explitives [sic] words of opprobrium, resistance."'1 "Many of the slang words," he suggests, "among fighting men, gamblers, thieves, prostitutes, are powerful words." 92

But a significant portion of the project of his Primer of Words consists of calling for the finding or forging of new words to resist and replace the old words of the Old World. "I think," he writes, "I am done with many of the words of the past hundred centuries.-I am mad that their poems, bibles, words, still rule and represent the earth, and are not-superceded [sic]." ${ }^{93}$ Whitman's manuscript is telling here, because before he wrote "done with," he wrote "startled at," and crossed it out, and before he wrote "mad," he wrote "terrified," 
and did the same: here the "poems, bibles," and "words" of the Old World constitute a very real threat to his American cultural independence. ${ }^{94}$ "California is sown thick," he writes, "with the names of all the little and big saints-(Chase them away and substitute aboriginal names." "All aboriginal names sound good ... " he says; "They are honest words. $"{ }^{\prime 95}$

To resist the influence of Europe, Whitman asks for new names for virtually everything: "No country can have its own poems," he writes, "without it have[ing] its own names." ${ }^{96} \mathrm{He}$ calls for an "escape" "from the shoals of Johns, Peters, Davids, Marys," and asks "could other words be prefixed or suffixed to these, to make them show who they are, what land they were born in, what government, which of The States . . . ?" ${ }^{\prime 97}$ America needs, Whitman feels, new names for its rivers, its places, towns, counties, and cities, and he singles out the city of Baltimore, named after the English Catholic Lord who was the original proprietor of the Maryland colony, as one of the "names to be Revolutionised," significantly written with a capital ' $R$ '.98 "The great proper names used in America," Whitman continues later:

must commemorate things belonging to America, and dating thence.-Because What is America for? To commemorate the old myths and the gods? To repeat the Mediterranean here? Or the uses and growths of Europe here?-No;-(Nä$\mathrm{o}-\mathrm{o}$ ) but to destroy all those from the purposes of the earth, and to erect a new earth in their place. ${ }^{99}$

In his manuscript notes, Whitman even calls for the creation of new names for the months, and the days of the week: "Now," he writes, "the days signify extinct gods and goddesses - the months half-unknown rites and emperors - and chronology with the rest is all foreign to America-All exiles and insults here." ${ }^{\prime 100}$ Whitman insists, in bellicose language evocative of the Declaration of Independence: "I have heard it said that when the spirit arises that does not brook submission and imitation, it will throw off all ultramarine names.-That spirit already walks the streets of the cities of These States-I, and others, illustrate it." ${ }^{\prime 101}$ For the moment, at least, Whitman leaves behind all notions of cultural growth and development to put forward a legitimate American Revolution of words. 
To be fair, a complete and utter rupture from the Old World is a quixotic idea that even Whitman must have known was impossible, and like the literary and political project of Coronel and the Nicaraguan Vanguardia, Whitman's new American Revolution has mixed failure with success. US readers have rightly insisted on still engaging and promoting the "poems, bibles, [and] words" of the past—as Whitman himself did-and on allowing them to shape and inform our own artistic, political, philosophical or theological labors. ${ }^{102}$ The inertia of habit and custom has preserved the old names for months and days, and Baltimore is - no doubt to Whitman's posthumous dismay-still called Baltimore. ${ }^{103}$ Still, Whitman's American Primer and the linguistic experimentation of poems like "Starting from Paumanok" were able to compel the imagination of José Coronel, who idealized Whitman's project of creating an authentic, autochthonous language and literature that could break from the influence-and Coronel might say "intervention"-of Europe.

Indeed, at least poetically, Whitman would likely have regarded Coronel and the Vanguardia as some of the intended heirs of what was to him a necessarily transnational literary and linguistic project. Whitman famously wrote in the Preface to the 1855 Leaves of Grass that "The Americans of all nations at any time upon the earth have probably the fullest poetical nature."104 As Folsom points out, the ambiguity here allows for the existence of "Americans" in other nations, who are heirs to, and in fact participants in, the American experiment-both poetic and political. ${ }^{105}$ As such, the Vanguardia's fierce expressions of autochthonous Nicaraguan language and poetics, employed to resist US intervention, intersect with Whitman's own New World resistance to the foreign cultural pressures of his day. Both Whitman and Coronel, then, across language, culture, politics, and the vast spaces of the American continents, sought to marshal the compelling linguistic power of "Nicaraguan words."

But if José Coronel's appropriation of Whitman has allowed us to see more clearly the US poet's own quest for cultural autonomy through his poetry and his "language experiment," this same appropriation might also lead us to reflect on some of the limitations underlying our own evaluation of Whitman's projects. As much as I, as a twenty-first 
century American, may sympathize with Whitman's culturally-open (if imperfect) embrace of indigenous words, his democratic celebration of American vernacular and slang speech, and his desire to establish a vibrant national literary culture, these same projects can be read just as seamlessly into a starkly different context: a twentieth-century Nicaraguan avant-garde seeking its own version of cultural autonomy, rooted in indigeneity and folk culture but doing so alongside its complicity in an overtly authoritarian political system. Or put another way, Americanists must face the possibility that US literature, in particular Walt Whitman, played some role in the aesthetic ferment of a fascist artistic movement that participated in the establishment of a corrupt and dynastic dictatorship. However, I would argue that this recognition should lead us neither to devalue Whitman's exceptional literary and cultural experiment nor simply to dismiss, for ethical or political reasons, the fascinating and important ways that the Nicaraguan Vanguardia engaged Whitman and US literature in response to the real problem of US imperialism and interventionism in Latin America. More than simply a reminder of the dangerous possibilities of nationalism, this transamerican literary encounter offers us an opportunity to reflect on the need for an element of detachment from historical and literary projects like Whitman's-projects whose seemingly-laudable goals twist, distort, or even disappear in unexpected ways when their author is transplanted (or translated) into a radically different context. Although José Coronel's exoticized tapir-Whitman may graze tranquilly wherever he lands, scholars of global and comparative Whitman studies, however, may not. Instead, this fascinating textual encounter signals for us the unexpected, unfamiliar, and even dangerous contexts into which Whitman's poetry and thought may flow.

Hillsdale College kfranklin@hillsdale.edu 


\section{NOTES}

I would like to thank Ed Folsom and Claire Fox for their feedback and encouragement as I worked on this piece. I would also like thank my research assistant, Emily DePangher, for her assistance in preparing the final manuscript.

1 José Coronel Urtecho, Rápido tránsito: al ritmo de norteamérica [Rapid Transit: To the Rhythm of The United States] (Managua: Editorial Nueva Nicaragua, 1985), 27. Hereafter, Rápido. See also José Coronel Urtecho, "El Americanismo en la casa de mi abuelo" ["Americanism in the House of My Grandfather"] Revista conservadora del pensamiento centroamericano [The Conservative Review of Central American Thought] 5.23 (1962), 25-31. In this essay, Coronel himself describes Whitman as "easily and totally translatable" ("fácil y totalmente traducible") (31). All translations are my own.

In this instance, I play on the alternate meaning of "translate" that involves movement to another place. As we shall see in this essay, to Coronel this universality does not at all undermine Whitman's project of expressing a distinct US culture and identity in his verse, a quality of Whitman's work that seized Coronel's imagination from his earliest readings of the US poet. See also Colleen Glenney Boggs, Transnationalism and American Literature: Literary Translation 1773-1892 (New York: Routledge, 2007). Boggs uses the notion of translation to argue for the paradoxical universality and national particularity of Whitman's writings. Although I am only partially convinced by her analogy between international literary translation and Whitman's mystical poetic expression of the material world, Boggs argues that because nineteenth-century US writers and editors regarded a translation both as a work of US literature and as a making-available of a foreign work, Whitman's "translation" of the natural, material, and spiritual worlds into US poetry sought to be both "nationally unique yet globally representative" (111-117, 123, 112).

2 See also Anna Brickhouse, Transamerican Literary Relations and the NineteenthCentury Public Sphere (Cambridge: Cambridge University Press, 2004). Brickhouse argues for trajectories of influence and confluence "across the unstable boundaries of nation and race within a New World arena characterized precisely by its transnationality," and posits that what she calls "transamerican literary relations . . . came to assume a central role in reshaping the public spheres of cultural production and political commentary in the United States and other parts of the American Hemisphere" $(7,8)$. See also Wai Chee Dimock, Through Other Continents: American Literature Across Deep Time (Princeton: Princeton University Press, 2008). Dimock goes even further, to call for recognition of American literature as situated within a far vaster global and historical network stretching across and between countless parts, texts, authors, and currents within what she calls "deep time" (3). Also see Dimock's "Hemispheric Islam: Continents and Centuries for American Literature," American Literary History 21 (2009), 28-52. Here Dimock criticizes the hemispheric model of American studies for reinscribing 
the Monroe Doctrine, for suffering from an "implicit geographical determinism," and for "assign[ing] more weight to one pair of continents, giving one directional axis an automatic primacy" (29). Both Brickhouse and Dimock make persuasive points: the crosscurrents between the nations and cultures of the American hemisphere are indeed many and deserve continued study, but to exclude the other axes of encounter would be to narrow our understanding of global literary history. As the following paragraph, and especially endnote 5 will show, Coronel's twentieth-century "transamerican literary relations" (to use Brickhouse's term) with Whitman nonetheless take place within a multi-layered context shaped deeply by a long - if not perhaps "deep" - century of contact and confrontation between the US and Nicaragua.

3 For the following summary of US-Nicaraguan relations, I rely heavily on Michele Gobat, Confronting the American Dream: Nicaragua Under U.S. Imperial Rule (Durham, NC: Duke University Press, 2005).

4 In addition to various military interventions in Nicaraguan affairs, the US had involved itself in Nicaraguan finances with President Taft's so-called "Dollar Diplomacy," which lasted until 1912, and by which US bank representatives managed Nicaraguan national finances, ostensibly seeking to stabilize the economy and to shore up the US-approved regime (Gobat 174). It is in these years that Nicaragua entered what Gobat describes as "the lengthiest occupation in Latin America" (Ibid. 100). When civil war broke out again in 1926, the US once more launched an invasion to reestablish democratic order, founding the Nicaraguan Guardia Nacional to ensure stable elections (Ibid. 205). Although the purpose of the Guardia "was to secure a stable, pro-US political order," this armed body would become the power by which the dynastic Somoza dictatorship would later rule Nicaragua for over half a century (Ibid. 206).

5 Urtecho, "Americanismo" 26. The original reads: "Mi actitud personal hacia los Estados Unidos fue mucho años ambivalente: me encontraba atraído, casi diría fascinado, y al mismo tiempo repelido por ellos."

6 The original reads: "Casi puedo decir que aprendí a leer inglés leyendo a Poe y Whitman.”

7 Likewise, in his extensive writings on Whitman, Coronel also cites from Whitman's prose prefaces as well as from Democratic Vistas and Whitman's posthumously-published linguistic notes, An American Primer.

8 Most studies of Whitman in Nicaraguan poetry have tended to focus instead on the earlier modernista poet, Rubén Darío, while those that treat Walt Whitman and the Nicaraguan Vanguardia have done so somewhat unevenly. See for instance, Fernando Alegría, Walt Whitman en Hispanoamérica [Walt Whitman in Latin America] (México: Ediciones Studium, 1954), 394, where Coronel receives only a mention. See also Jorge Eduardo Arellano, El movimiento de vanguardia de Nicaragua: 1927-1932, Germenes Desarrollo Significado [The Vanguard Movement 
in Nicaragua: 1927-1932, Origins, Development, Significance] (Managua: Librería Cultural, 1969), 62. Arellano portrays Whitman as merely the influential backdrop to poets like Vachel Lindsay and Carl Sandburg - favorites of Coronel and the Vanguardia. See also Antonio Melis, "Whitman nella poesia nicaraguense del '900. (Il paradigma civile e il paradigma stilistico)" ["Whitman in Nicaraguan poetry of the 1900s. (The Civil Paradigm and the Stylistic Paradigm)"] Letterature d'America 3 (Autumn 1982), 117-141. Melis offers the most sophisticated exploration of Coronel and Whitman, pointing out Coronel's understanding of the links between Whitman's poetry and Emerson's thought, especially in Whitman's search for "[t]he new language and the new rhythm" ["[i]l nuovo linguaggio e il nuovo ritmo"] (125); however, Melis laments later on that "[i]t is not possible on this occasion to analyze the penetration and re-creation of the Whitmanian language in Coronel Urtecho" ["Non è possibile in questa occasione analizzare la penetrazione e la ricreazione del linguaggio whitmaniano in Coronel Urtecho"] (128). See also Steven White, Modern Nicaraguan Poetry: Dialogues with France and the United States (Lewisburg, PA: Bucknell University Press, 1993). White traces how the Vanguardia appropriated US literature, and notes Coronel's fascination with Whitman's depiction of America (146); yet his treatment downplays Coronel's complex critical writings on Whitman, and emphasizes Coronel's and the Vanguardia's engagement with twentieth-century US literary culture. See also Fernando Alegría, "Whitman in Spain and Latin America," Whitman and the World, ed. Gay Wilson Allen and Ed Folsom (Iowa City, IA: University of Iowa Press, 1995), 71-127, and also Jim Perlman, Ed Folsom, and Dan Campion, eds., Walt Whitman: The Measure of His Song (Duluth: Holy Cow! Press), 1998. Both works overlook Coronel's writings on Whitman. See more recently, Pedro Xavier Solis, El movimiento de vanguardia de Nicaragua: análisis y antologia [The AvantGarde Movement of Nicaragua: Analysis and Anthology] (Managua: Fundación Vida, 2002). His book acknowledges Whitman's importance for Coronel's "formation as a poet" but says nothing about Whitman's specific significance or role (29).

9 José Coronel Urtecho, "Los yanquis, poetas" ["The Yankees, Poets"], El diario nicaragüense [The Nicaraguan Daily], 2 Oct. (1927), 2. The original reads: "En libros rezagados que son manuales de espíritu entre nosotros se dice todavía la vieja afirmación de que los yankis son colonos literarios de Inglaterra."

10 Although at this point in his career he dates the "true artistic Renaissance" ["verdadero renacimiento artístico"] of the US from 1913, he implies that the project really begins with Whitman's and Poe's establishment of a US literature, distinct from, and influential for, world literature (Urtecho, "Yanquis" 2).

11 José Coronel Urtecho, "Anotaciones sobre literatura norteamericana: Poe, Walt Whitman, Emerson, etc" ["Annotations on US Literature: Poe, Walt Whitman, Emerson, etc"] Revista conservadora del pensamiento centroamericano [The Conservative Review of Central American Thought] 10.47 (1974), 70-80. Written in 1946 and 1947 but published in 1974, this essay by Coronel collects some of his 
musings and notes about Emerson, Poe, and Whitman. For this work, Coronel does not use punctuation, so all spacing and lack of punctuation is original.

12 Urtecho, "Anotaciones" 74-75. The original reads: "Tomar ... [a] todo, desde nuevos aspectos, nuevos puntos de vista diferentes de los antiguos, con una nueva libertad e independencia para crear una nueva poesía que formara, a su vez, un nuevo tipo de hombre ... ese era el ideal de Walt Whitman. Y para él debía de ser también el de la literatura americana."

13 José Coronel Urtecho, Panorama y antología de la poesía norteamericana [Panorama and Anthology of US Poetry] (Madrid: Seminario de Problemas Hispanoamericanos, 1949), 53. The original reads: "genio de la verdadera Independencia Americana, del permanente espíritu revolucionario de las tierras y del pueblo de América."

14 José Coronel Urtecho, "Los intelectuales y los hombres de empresa" ["Intellectuals and Businessmen"], in Tres conferencias a la empresa privada: y epilogo en memoria de foaquin Zavala Urtecho. [Three Conferences on Private Business: and Epilogue in Memory of foaquin Zavala Urtecho] (Nicaragua: Ediciones el Pez y la Serpiente, 1974), 5-45, 15-16. The original reads: "la trinidad independizadora, y aún, en cierta medida, iniciadora de la poesía propia del continente americano, $\mathrm{y}$ hasta quizá también en un cierto sentido de la cultura americana continental."

15 Urtecho, "Americanismo" 31.

16 Ibid. The original reads: "el más 'americano,' inconcebible fuera de su país."

17 Ibid. The original reads: "Su poesía fue para mí desde el principio y, en cierto modo, aun sigue siendo, los Estados Unidos."

18 Ibid. The original reads: "una amplitud de proporciones continentales, con inmensos espacios abiertos y horizontes ilimitados, un poderoso aliento oceánico . .. un coro unánime de millones de voces, una visión profético y multitudinaria de incontenibles pueblos en marcha . . . el descubrimiento, mejor diría, la revelación del mundo americano."

19 Ibid. The original reads: "me imaginaba abigarradas multitudes invadiendo pacíficamente territories sin límites, cruzando inmensos ríos . . . edificando por todas partes millares de aldeas y grandes ciudades trepidantes de maquinarias y de vehículos."

20 The original reads: "Su poesía era de la tierra, y sobre todo de la tierra y del pueblo de América."

21 The original reads: "Había oído—decía él—pedir algo para descifrar este enigma de América, y por eso nos enviaba sus cantos, para que contempláramos en ellos lo que deseábamos."

22 The original reads: "El bello bardo de barba blanca nos traía un programa de cantos para América." 
23 Walt Whitman, "Starting from Paumanok," in Leaves of Grass, (Philadelphia: David McKay, 1891-92.), 3. Available on the Walt Whitman Archive (www.whitmanarchive.org).

24 Ibid. 26.

25 Ibid. 27.

26 Walt Whitman, An American Primer by Walt Whitman: With Facsimiles of the Original Manuscript, ed. Horace Traubel (Boston: Small, Maynard \& Company, 1904), 30.

27 "He was the adamic poet, edenic, like Adam in Paradise giving name to things. He was enamored of all the words and of all the things, and wanted for his language, as he said in his American Primer, words from Canada, Yankee words, words from Manhattan, words from Virginia, words from Florida and from Alabama, words from Texas, Mexican and Nicaraguan words, Mexican and Nicaraguan words."

28 Quoted in Arellano 7. The original reads: "literatura autóctona, de sabor nicaragüense"; "fuerzas generadoras de una cultura nacional. . .."

29 Quoted in Ibid. 7. The original reads: "Nacen extranjeros de la tierra natal y van a la escuela liberal para salir completamente desenraizados."

30 Quoted in Ibid. 12. The original reads: "una cultura en formación, una cultura cosmopolita que es la cultura yanqui. ..."

31 Quoted in Ibid. The original reads: "¿cuándo comenzaremos los jóvenes nicaragüenses a embebernos en la cultura nicaragüense?"

32 Bruno Mongalo, et al., "Ligera exposición y proclama de la anti-academia nicaragüense" ["A Modest Exposition and Proclamation of the Anti-Academy of Nicaragua"], in Las Vanguardias latinoamericanas [The Latin American AvantGardes] (México: Fondo de Cultura Económica, 2002), 238-241, 25. The original reads: "dar rienda suelta a la emoción de ser y estar en Nicaragua"; "emprender la recreación artística de Nicaragua."

33 Mongalo et al., "Ligera" 25. The original reads: "hasta de la dinamita y del fusil literarios. ..."

34 The original reads: "El éxito del recital fue completo. En Granada explotó como una bomba. Hasta se llegó a decir que en él se habían recitado poemas inmorales, queja que llegó a oídos del Obispo. Pero los Salesianos defendieron a los vanguardistas y el asunto quedó concluido."

35 "La Fratria Nicaragüense" ["The Nicaraguan Brotherhood"], Vanguardia (1932), in 50 aniversario del MOVIMIENTO DE VANGUARDIA de Nicaragua [50th Anniversary of the VANGUARD MOVEMENT of Nicaragua], ed. Pablo Antonio Cuadra, Spec. issue of El Pez y la Serpiente [The Fish and the Serpent] 28-29 (197879), 76-77, 77. The original reads: 
Se va perdiendo la lengua.

Se va perdiendo la religión.

Se va perdiendo el honor.

Se va perdiendo la tierra.

La intervención está intentando la conquista de nuestro pueblo.

36 José Román, "Preludio a Managua en B Flat (Con acompañamiento de english)" ["Prelude to Managua in B Flat (With accompaniment in English)," in Antología General de la Poesía Nicaragüense, ed. Jorge Eduardo Arellano (Managua: Ediciones Distribuidora Cultural, 1994), 276-277, 276.

Calles pavimentadas, carretas

y buses. Lagunas que sueñan como viejos poetas

y un lago que ríe, que canta que tiembla Gentes elegantes, coches, carretones, indios, mendicantes.

\section{Román 227.}

The Canal, the Yankees and the liberals, the conservatives and all politics, crazy illusions ...

Pasteurized milk and Club and Jazz Band and everywhere an English spoken.

'How many of us millions of souls will speak English.' Yes Sir.

38 Ibid. The original reads: "todo es extranjero ..."; "hasta tu catedral es importada . . . Pronto en ella veremos un Dios English speaking."

39 Ibid. The original reads: "when he awakes you will tell him: No Spanish."

40 Vicky Unruh, Latin American Vanguards: The Art of Contentious Encounters (Berkeley: University of California Press, 1994), 210.

41 See Vera Kutzinski, Sugar's Secrets: Race and the Erotics of Cuban Nationalism (Charlottesville, VA: University of Virginia Press, 1993). In her chapter, "Antidote to Wall Street," for instance, Kutzinski argues persuasively that in Cuba the move toward celebrating Afro-Cubanism became a means for writing back against the cultural and economic encroachments of the US. As such, Kutzinski argues, "the syncretic forms of Afro-Cuban popular music and dance became the new signifiers of a desire for cultural and political independence" (154). Just as Cuban nationalists used Cuban ethno-culture to shore up national identity, the Vanguardia turned, as Whitman had, to a cultural and linguistic heritage they felt made their nation unique.

42 Kutzinski argues, for instance, that Afrocubanismo's commitment to national and cultural unity in the face of external threats tended to elide real injustices within Cuba, running the risk of becoming "a folkloric spectacle whose political effect was to displace and obfuscate actual social problems and conflicts, especially racial ones" (Sugar's Secrets, 143). Additionally, Kutzinski also reveals how cultural 
rhetorical moves such as this, in conflict with an external enemy, can nonetheless remain complicit in "further entrenching racially and sexually determined social hierarchies" (Ibid. 10).

43 Chadwick Allen, Trans-Indigenous: Methodologies for Global Native Literary Studies (Minneapolis: University of Minnesota Press, 2012), xv.

44 Without denying the need for continued work understanding specific indigenous traditions, Allen draws our attention to the "mobility and multiple interactions of Indigenous peoples, cultures, histories, texts" (xiv). As such, Allen proposes "to develop a version of Indigenous literary studies that locates itself firmly in the specificity of the Indigenous local while remaining always cognizant of the complexity of the relevant Indigenous global" (xix).

45 A good example of the difference might be seen in Allen's reading of Apirana Taylor's bilingual English-Maori poem "Sad Joke on a Marae." Allen writes: "Taylor's poem emphasizes the role of Maori language and public oratory in this representation of an enabling contact with Indigenous ancestors. Through the primary symbol of the ancestor's tongue, the poem asserts the recuperative power of speaking as an Indigenous person in an Indigenous space and in an Indigenous manner" (Allen 49-150).

\section{La Fratria 77.}

47 An earlier text that enacts this experiment on the level Nicaraguan phonemes and morphemes is the 1931 collaborative poem-play Chinfonía Burguesa [Bourgeoise Chinfony], by Coronel and Joaquín Pasos, which combines folk-rhyming and vernacular nonsense wordplay in a cartoonesque satire of the bourgeoisie. Vicky Unruh describes this play as "a manifesto of linguistic nationalism" (Unruh, Contentious 229). See also Unruh, "The Chinfonía Burguesa: A Linguistic Manifesto of Nicaragua's Avant-Garde," Latin American Theater Review 20.2 (Spring 1987), 37-48. In this article, Unruh situates the work within a larger body of Latin American "hybrid works which combined self-consciously vanguardist strategies with elements of autochthonous expression" (38).

48 Pablo Antonio Cuadra, "Inventario de algunos recuerdos" ["Inventory of Some Memories"], in Poemas Nicaraguenses [Nicaraguan Poems] (Santiago, Chile: Editorial Nascimento, 1934), 7-8, 8. Nahuatl seems to have mixed with Spanish as far south as Nicaragua. See for instance A.M. Elliot, "The Nahuatl-Spanish Dialect of Nicaragua," The American fournal of Philology 5.1 (1884), 54-67. Cuadra's use of Nahuatl words here more importantly reflects, from his perspective, the daily words that Nicaraguans used for their experienced reality.

49 Cuadra, "Inventario" 8.

50 Ibid. 11.

51 Pablo Antonio Cuadra, "Poema del momento extranjero en el bosque" ["Poem of the Foreign Moment in the Jungle"], in Poemas nicaragüenses 25-28, 26-27. The 
original reads: "un árbol férrico en paralela elevación al cocotero. . .." However, as Gobat points out, Sandino's troops were themselves guilty of atrocities as well (Confronting 238).

52 Cuadra, "Poema" 27. The original reads: "el conjunto de nuestros civilizados salvajismos / Refugio de la ignorada justicia del templo verde y sonoroso / Vierte una protesta orgullosamente diminuta."

53 Ibid. The original reads: "Y he aquí que presenciamos el retiro precipitado de 500 norteamericanos / Pálidamente derrotados por nuestra malaria iracunda y vengadora."

54 Members of the Vanguardia even propagandized for Sandino, and once vandalized the elite club in Granada with pro-Sandino slogans (Gobat, Confronting 240). See also Manolo Cuadra, El gruñido de un bárbaro: visions y confesiones, ed. Fulio Valle-Castillo (Managua: Editorial Nueva Nicaragua, 1994), 183-184.

55 See Arellano 69 and Gobat, Confronting 233-234.

56 See Gobat, Confronting 263-264.

57 The group's desire for a strong authoritarian government to restore stability and autonomy to Nicaragua, as well as Somoza's connections to Granada's conservatives, led the members to overlook his ties to the US and to support him in his bid for power (Gobat, Confronting 272). See also John Beverley and Marc Zimmerman, Literature and Politics in the Central American Revolutions (Austin: University of Texas Press, 1990), 61. Beverley and Zimmerman reveal that in the pages of his periodical La Reacción, which they classify as "proto-fascist," and elsewhere, Coronel and his Vanguardia supported Somoza's rise to power (61). See also Joaquín Pasos, "Se necesita un hombre" ["We Need a Man"], in Prosas de un joven [Prose of a Youth], by Joaquín Pasos, ed. Julio Valle-Castillo, 2 vols. (Managua: Editorial Nueva Nicaragua, 1994), 1:169-171, where group member Pasos himself called for Somoza to take leadership and implicitly considers Somoza the potential savior of Nicaragua (169-171); Joaquín Pasos, "Politics, an Issue for the Youth" ["La política, cuestión de jóvenes"], Prosas de un joven, 1:177-180, In this essay from the same year, Pasos quotes Benito Mussolini insisting that "the people have been thirsting for authority, for directive, for order" ["los pueblos han estado sedientos de autoridad, de directiva, de orden"] (178).

58 As Gobat puts it: "these elite Conservatives drew their main inspiration not so much from fascist Italy and Nazi Germany as from Catholic corporatist dictatorships such as Primo de Rivera's Spain (1923-30), Salazar's Portugal (1932-68), and Dollfuss's Austria (1932-34), as well as from Catholic-based movements like the Action Française and Argentina's Nationalists (Confronting 221-224).

59 Quoted in Arellano 55. The original reads: "falsa en sí misma y por lo tanto impracticable"; "ha sido instrumento de engaño que usaron los ambiciosos y aventureros de todas partes para llevar al pueblo a la matanza." 
60 Quoted in Arellano 55. The original reads: "La democracia es un principio de desorden y de caos, mortal para los pueblos latinos, y sobre todo para nosotros."

61 Jorge Eduardo Arellano, "Coronel Urtecho, José," Diccionario de escritores centroamericanos [Dictionary of Central American Writers] (Managua: ASDI-Bibliotecas Nacionales de Centroamérica y Panamá, 1997). Coronel was appointed Subsecretary of Public Instruction in 1938, later served in the legislature.

62 Tim Merrill, ed., Nicaragua: A Country Study (Washington, D.C.: Federal Research Division, Library of Congress, 1994). Library of Congress. Web. 29 Aug. 2013. lcweb2.loc.gov/frd/cs/nitoc.html.

63 Arellano writes, perhaps with a touch of chauvinism: "The ideal of the reactionaries, then, had failed. They wanted to reestablish hierarchical order, to impose respect of power, to restore the Church to her true place, to promote religious instruction and to combat immorality; finally . . . as is well known, the failure was total" ["El ideal de los reaccionarios, pues, quedó frustrado. Ellos querían restablecer el orden jerárquico, imponer respeto al poder, reponer a la Iglesia en su verdadero lugar, promover la enseñanza religiosa y combatir la inmoralidad; en fin; . . como se sabe, el fracaso fue rotundo"] (Arellano 56).

64 José Coronel Urtecho, Conversando con fosé Coronel Urtecho [Conversing with Fosé Coronel Urtecho], published interview with Manlio Tirado (Managua: Editorial Nueva Nicaragua, 1983), 23. The original reads: "Eran locuras de muchachos al fin y al cabo, no nos poníamos a pensar seriamente en el asunto. . .."

65 Ibid. 128. The original reads: "No tenía más ganas que de retirarme y de apartarme poco a poco, que es lo que fui haciendo."

66 Arellano, "Coronel Urtecho."

67 Contrast, for instance, the movement's anti-democratic sentiments with this excerpt from Pablo Antonio Cuadra's poem "Ars Poetica," (in Cuadra, 50 aniversario 30-31):

and let the song not banish the glint of the griddle;

may the day-worker be able to say it in his work, let the guitar player sing it and later the vaquero repeat it in the corral.

[y que el canto no extrañe a la luz del comal;

que lo pueda en su trabajo decir el jornalero, que lo cante el guitarrero y luego lo repita el vaquero en el corral.

68 Although Whitman imagines a Democratic America that includes common people across class, race, and gender, there is still only an equivocal sense in which Whitman's incorporation of indigenous words reflects a real political desire to include actual Native Americans in the polity. See Ed Folsom, Walt Whitman's Native Representations (Cambridge: Cambridge University Press, 1997). As Folsom 
describes, Whitman fought hard to preserve and uphold Native American culture and language as a part of a diverse and autochthonous US culture, even while he nonetheless subscribed to the myth that Native Americans were already inevitably on their way to extinction (55-98).

69 Urtecho, Conversando 138. The original reads: "Yo no soy enemigo de los gobiernos fuertes como tales ... gobierno fuerte. ..."

70 Ibid. 138-139. The original reads: “¿Cómo no va a ser un gobierno fuerte si es el gobierno del pueblo? Se identifica con el pueblo. Los sandinistas son la parte consciente, luchadora, la parte que ha venido surgiendo del pueblo mismo y nunca se ha separado de ese pueblo, ni se piensa separar, porque está totalmente identificada moral e intelectualmente con ese pueblo."

71 The party's official name is the Frente Sandinista de Liberación Nacional, or the Sandinista National Liberation Front.

72 Ernesto Cardenal, "El grupo de vanguardia en Nicaragua" ["The Vanguardia Group in Nicaragua"] reprinted in Revista de critica literaria latinoamericana [Review of Latin American Criticism] 8.15 Las Vanguardias en América Latina (1982), 7176, 74. “...lucha nacional....” See also Ernesto Cardenal, interview by Margaret Randall, in Risking a Somersault in the Air, ed. Floyce Alexander, tr. Margaret Randall (San Francisco, CA: Solidarity Publications, 1984), 89-108. Cardenal and Coronel were in fact, relatives, and Coronel mentored the young Ernesto, introducing him to US literature.

73 Ibid. 74. The original reads: "La lucha fue larga; pero ahora, quince años después, aquellas páginas de Vanguardia, y amarillentas y marchitas, han triunfado plenamente en la juventud."

74 See Folsom, Native 15-18; James Perrin Warren, Walt Whitman's Language Experiment (University Park, PA: The Pennsylvania State University Press, 1990), 113. Chapters two and four of Warren's book also speak to this notion.

75 In his chapter "Whitman and Dictionaries," Ed Folsom does acknowledge Whitman's endorsement of what he calls the "declaration of American linguistic independence" proclaimed, among others, by dictionary maker Noah Webster (Native 13); but the chapter focuses on other aspects of Whitman's multifaceted linguistic project, and identifies Whitman's An American Primer primarily as "a program for expanding the lexicon" (Ibid. 21). My only qualification of this is that it risks muting the real desire Whitman has for a radical linguistic rupture with the Old World, as both Coronel's reading of Whitman and the passages I will signal suggest.

76 See for instance Richard H. Brodhead, "Literature and Culture, 1865-1910," in The Columbia Literary History of the United States, ed. Emory Elliot, et al. (New York: Columbia University Press, 1988), 467-481. Brodhead writes that "the sizeable American consumption of literary works did not much extend, at first, to 
native productions. The cultural legacy of America's colonial situation was that America continued to import both its literature and the terms by which it judged its literature from England long after it had achieved its political independence" (467-468).

77 See Kenneth M. Price, Walt Whitman and Tradition: The Poet in His Century (New Haven: Yale University Press, 1990), 4. Price writes that for US authors "it was with their exact contemporaries, the Victorians, that the real wrangling began; it was the Victorians, after all, who were their competitors for shelf space in the bookstores and for public approbation" (2-3).

78 Sydney Smith, "Review of Statistical Annals of the United States of America, by Adam Seybert," The Edinburgh Review 33 (January 1820), 69-80.

79 Alexis de Tocqueville, Democracy in America, tr. Henry Reeve, vol. 1.

80 Ralph Waldo Emerson, "The Poet," in Essays and Poems, ed. Joel Porte, Harold Bloom, and Paul Kane (New York: Library of America, 1996), 447-468, 465.

81 See Elisa Tamarkin, Anglophilia: Deference, Devotion, and Antebellum America (Chicago: University of Chicago Press, 2008). Tamarkin offers a sophisticated cultural study of why many nineteenth-century Americans loved all things English, but offers a solution other than a simple notion of cultural dominance. Taking as one illustrative example the antebellum US fascination with the English monarchy, Tamarkin argues that what she calls "American Anglophilia," cannot be understood as "the aftershocks of British rule" but rather that it "emerges from within the psychology of democratic life itself" (xxv). She goes on to describe "a much broader fascination with English society and its traditions" that Americans practice "because it allows for the relations between a diverse cast of Americans who share little with one another save for the way that Englishness appeals to them" (xxvi). Linking this desire to nationalism in a way that applies as much to Coronel as it does to Whitman, Tamarkin describes "how nationalism, as a form of feeling, an ideology, and a set of practices, works every bit as seriously at bringing some aspects of the outside in, as it does at keeping others out" (xxvi). Whatever the reasons for this situation, many US authors rankled under the sense of always being on the literary periphery, and they reacted and wrote accordingly.

82 Walt Whitman, "Song of the Exposition," in LG1892, 160.

83 Walt Whitman, Leaves of Grass (Brooklyn, NY: 1855), 5-26, 5; available online at the Walt Whitman Archive.

84 Ibid. 5.

$85 L G 1892,183$. As another example, see for instance "Thou Mother With Thy Equal Brood," (Ibid. 346-351). Whitman here writes to America:

The conceits of the poets of other lands I'd bring thee not, Nor the compliments that have served their turn so long,

Nor rhyme, nor the classics, nor perfume of foreign court or indoor library; 
But an odor I'd bring as from forests of pine in Maine, or breath of an Illinois prairie (374).

86 R.W.B. Lewis, The American Adam: Innocence, Tragedy, and Tradition in the Nineteenth Century (Chicago: University of Chicago Press, 1955), 48.

87 Floyd Stovall, The Foreground of Leaves of Grass (Charlottesville: University Press of Virginia, 1974). Stovall's book offers us an understanding of Whitman's "process of education" by working through "the materials he [Whitman] used and preserved" (16). In this impressive monograph on Whitman's sources and formation, he reveals Whitman's readings of-among others-George Sand, Milton, works on Ancient Egypt, German literature such as the Nibelungenlied, Voltaire, Heinrich Heine, and Whitman's contemporary Lord Alfred Tennyson (12, 126, 162-163, 196, 208, 222, 252-264).

88 Price writes, “The sheer energy of Whitman's denials of connectedness with literary high culture, particularly in his great early phase, suggests that more attention should be paid to his defensive strategy" (Walt Whitman and Tradition 4).

89 Quoted in Horace Traubel, "Foreword," in An American Primer by Walt Whitman: With Facsimiles of the Original Manuscript, by Walt Whitman, ed. Horace Traubel (Boston: Small, Maynard \& Company, 1904), v-ix, ix. Available on the Walt Whitman Archive.

90 See Folsom, Native 21 and Warren, Walt Whitman's Language 41.

91 Whitman, Primer 741.

92 Ibid. 735.

93 Ibid. 739.

94 Ibid.

95 Ibid. 752, 743. This assessment of the truth-value of aboriginal words, I would argue, places Whitman squarely in the trajectory of linguistic thought absorbed by the Transcendentalists. See Philip F. Gura, American Transcendentalism: A History (New York: Hill and Wang, 2007), 40-42.

96 Whitman, Primer 574.

97 Ibid. 744-745.

98 Ibid. 752.

99 Ibid. 755. Here Whitman spells out the word "No" phonetically, perhaps for oral emphasis (the notes were for intended lectures).

100 Ibid. Whitman's Quaker ancestors renamed the days and months, refusing to celebrate the pagan gods who gave their names to much of the western calendar. Whitman gives this act a nationalist twist, having no such religious conviction but objecting to the importation of foreign names for "American" realities. See for instance "Out of the Cradle Endlessly Rocking," in LG1892, 196-201; Whitman 
uses the Quaker "Ninth-month" and "Fifth-month" to replace September and May (Ibid. 19). See also "Song of Myself" (LG1892, 29-78), where in addition to his famous neologism, "yawp," Whitman borrows "Eleves" from French (78, 65); "Kosmos" (Ibid. 303-304), where he draws on the Greek "Kosmos" (303); "As I Lay with My Head in Your Lap Camerado" (Ibid. 251), for his incorrect borrowing from Spanish, "Camerado." See also Roger Asselineau, "Foreign Language Borrowings," Walt Whitman: An Encyclopedia, eds. J.R. LeMaster and Donald D. Kummings (New York: Garland Publishing, 1998). Asselineau describes Whitman's adoption and adaptation (not always successful or even deliberate) of foreign words, and points out that "[n]o other American writer of his time made so many language borrowings as Whitman. He did so despite his great admiration for the English language and his rejection (in principle) of European influences. Still, his generous adoption of foreign words was consonant with his desire to incorporate all races and address all the nations - and also with his love of rhetoric and high-soundings words" (229). Yet there is also a way in which we can see Whitman submitting these foreign words to a process of naturalization, absorbing them like immigrant peoples into the great melting pot of his (and the) American idiom.

101 Whitman, Primer 755. The US Declaration of Independence of 1776 famously states that " it is their Right, it is their Duty, to throw off such Government [i.e. Despotism]."

102 Whitman, Primer 739.

103 Folsom also points out that fewer Native American words made it into the dictionary than Whitman would have hoped (Native 88).

104 Whitman, LG1855 5.

105 Ed Folsom, “'What A Filthy Presidentiad!': Clinton's Whitman, Bush's Whitman, and Whitman's America," Virginia Quarterly Review 81.2 (2005), 96113,108 . Folsom writes here: "We can hear this sentence of course in a couple of ways-'out of all the nations on earth, Americans have the fullest poetical nature,' or, 'Americans of all nations' have the fullest poetical nature. In the first reading, 'America' is synonymous with the 'United States,' but in the second 'America' designates not a nation but a quality - here a quality that nurtures the poetic nature-available in all nations" (108). 